\title{
Application of Biotests for the Determination of Soil Ecotoxicity after Exposure to Biodegradable Plastics
}

OPEN ACCESS

Edited by:

Weiwen Zhang,

Tianjin University, China

Reviewed by:

Uwe Strotmann,

Westfälische Hochschule, Germany Luciano Takeshi Kishi,

Universidade Estadual Paulista

UNESP/FCAV, Brazil

*Correspondence: Aldo Viarengo

aldo.viarengo@uniupo.it

Specialty section:

This article was submitted to Microbiotechnology, Ecotoxicology

and Bioremediation,

a section of the journal

Frontiers in Environmental Science

Received: 28 July 2016 Accepted: 07 October 2016 Published: 28 October 2016

Citation:

Sforzini S, Oliveri L, Chinaglia S and Viarengo A (2016) Application of Biotests for the Determination of Soil

Ecotoxicity after Exposure to Biodegradable Plastics.

Front. Environ. Sci. 4:68.

doi: 10.3389/fenvs.2016.00068

\author{
Susanna Sforzini, Laura Oliveri, Selene Chinaglia and Aldo Viarengo * \\ Department of Sciences and Technological Innovation, University of Piemonte Orientale "A. Avogadro", Alessandria, Italy
}

Biodegradable plastics are mostly applied in packaging materials (e.g., shopping bags), waste collection bags, catering products, and agricultural applications. In this last case, degradation takes place directly in soil where biodegradable plastic products are intentionally left after use (e.g., mulch films for weeds control). Due to the growing volumes of biodegradable polymers and plastics, interest in their environmental safety is increasing and more research is carried out. Some attempt has been made to apply biotests, used in other sectors of environmental sciences, in the assessment of biodegradable plastics safety. In this work, the quality of soils after biodegradation of the bioplastics Mater-Bi has been assessed with a large array of biotests based on model organisms representative of the different trophic levels in the food chains of the edaphic and aquatic ecosystems. Mater-Bi was degraded under controlled conditions for 6 months at a 1\% concentration. The selected organisms included bacteria and protozoa (Vibrio fischeri and Dictyostelium discoideum, respectively), the green alga Pseudokirchneriella subcapitata, plants (the monocotyledon Sorghum saccharatum and the dicotyledon Lepidium sativum), and invertebrates animals (Daphnia magna, a freshwater crustacean, and the Oligochaeta earthworm Eisenia andrei), using both acute and chronic endpoints. The results of the applied ecotoxicological tests showed that the Mater-Bi materials tested at very high doses did not affect the soil quality. Soil exposed to Mater-Bi has no noxious effects on edaphic organisms; in particular, mono and dicotyledon plants results, indicate that Mater-Bi plastic products are innocuous for agricultural uses. The use of more sensitive chronic endpoints allows to exclude possible effects at population level. This is the first time that such a comprehensive approach is applied to the assessment of possible ecotoxicity effects induced by biodegradable plastics in soil and represents a possible starting point for improved standardized testing schemes.

Keywords: biodegradable plastics, ecotoxicological tests, edaphic organisms, Mater-Bi, soil quality

\section{INTRODUCTION}

Biodegradable plastics are mostly applied in packaging materials (e.g., shopping bags), waste collection bags, catering products, and agricultural applications (Shen et al., 2009). At the end of their commercial life these products are expected to degrade into harmless end products. Degradation takes place in composting plants or in anaerobic digestion plants (van der Zee, 2014) 
together with the bio-waste (food and yard waste) to give rise to compost. Compost is applied to soil as a fertilizer in order to increase organic matter. Degradation can also take place directly in soil where biodegradable plastic products are intentionally left after use (e.g., mulch films for weeds control). Since the agricultural soil is the medium for the production of food for humans and feed for farm animals, the absence of negative effects linked to applications of biodegradable plastics is of great concern to the interested parties. That is why all the testing protocols developed to characterize the biodegradable plastics and packaging include the assessment of ecotoxicity potentially originated from the biodegradation. Standards have been developed to specify the requirements for biodegradable plastics and packaging in composting (i.e., organic recycling), in home composting, and in soil. The most relevant standards on plastics that are biodegradable in different environments are shown in Table 1. All standards require (i) full biodegradation levels as a first tier of testing that prevents accumulation in soil and (ii) ecotoxicity testing as a second tier of testing in order to show environmental safety. The testing approach is similar in all cases: the plastic material is exposed to the matrix of interest (e.g., compost, soil) in a very high dose and let biodegrade. After a given time, a sample of the matrix is tested with biotests for ecotoxicity together with a control sample not exposed to the plastic item and a control sample exposed to a GRAS (Generally Recognized As Safe) substance, such as cellulose. No significant difference must be found between the test samples and control samples.

The standards on compostability (e.g., EN 13432) requires ecotoxicity assessment on compost samples where plastic material added at a $10 \%$ concentration has been composted for 3 months. The biological test is based on a germination and growth assay with two plant species and derives from the OECD 208 Guidelines for testing of chemicals (OECD, 2006).

Ecotoxicity requirements are also enforced by the standards on biodegradability in soil (the Italian and French national standards and the "OK Biodegradable soil" certification programme). Ecotoxicity tests must be carried out on soil samples where plastic material added at a $1 \%$ concentration has been degraded for 3 months. The prescribed concentration of plastics is much higher of the amount that is expected to end up normally in the environment. A $1 \%$ loading is much higher than the expected application loading of biodegradable plastics in soil. For example: a typical biodegradable plastic film for mulching is $1.5 \times 10^{-5} \mathrm{~m}$ thick and has a density of $1250 \mathrm{~kg} \mathrm{~m}^{-3}$. This means $1.88 \times 10^{-2} \mathrm{~kg} \mathrm{~m}^{-2}$ for one application. The soil depth where the plastic is typically used or remains after use is presumed to be $0.20 \mathrm{~m}$, in agreement with the normal depth of soil tillage. Therefore, $1 \mathrm{~m}^{2}$ of plastic film covering $1 \mathrm{~m}^{2}$ of soil surface will typically be mixed with a volume of soil equal to $0.2 \mathrm{~m}^{3}$. This amount of soil weighs $\sim 300 \mathrm{~kg}$, considering a soil bulk density of $1500 \mathrm{~kg} \mathrm{~m}^{-3}$. Therefore, the typical loading of the plastic film in normal use will be $\sim 0.0063 \%\left(1.88 \times 10^{-2} \mathrm{~kg} / 300 \mathrm{~kg} \times 100\right)$.

The ecotoxicity biotests required by the different standards are shown in Table 2.

The current approaches to the standardization of composting and soil biodegradation are considered satisfactory and suitable for the assessment of the environmental safety of biodegradable plastics (Fritz, 2014). The reason lies in the very high mineralization threshold levels $(90 \%)$ required by these

TABLE 1 | Main standards on plastics and packaging that are biodegradable in different conditions.

\begin{tabular}{|c|c|c|}
\hline Standard & Topic & Issued by: \\
\hline $\begin{array}{l}\text { EN 13432, Packaging - Requirements for packaging recoverable through } \\
\text { composting and biodegradation-Test scheme and evaluation criteria for } \\
\text { the final acceptance of packaging }\end{array}$ & Organic recyclability of packaging & $\begin{array}{l}\text { CEN Comité européen de normalization, } \\
\text { Bruxelles, Belgium }\end{array}$ \\
\hline ISO18606 Packaging and the environment-Organic recycling & Organic recyclability of packaging & $\begin{array}{l}\text { ISO International Organization for } \\
\text { Standardization, Geneva, Switzerland }\end{array}$ \\
\hline $\begin{array}{l}\text { EN 14995, Plastics - Evaluation of compostability - Test scheme and } \\
\text { specifications }\end{array}$ & Compostability of plastics & $\begin{array}{l}\text { CEN Comité européen de normalization, } \\
\text { Bruxelles, Belgium }\end{array}$ \\
\hline ISO 17088, Specifications for compostable plastics & Compostability of plastics & $\begin{array}{l}\text { ISO International Organization for } \\
\text { Standardization, Geneva, Switzerland }\end{array}$ \\
\hline ASTM D6400, standard specification for compostable plastics & Compostability of plastics & $\begin{array}{l}\text { ASTM International, West Conshohocken, } \\
\text { Pennsylvania, } 1999\end{array}$ \\
\hline $\begin{array}{l}\text { NF U 52-001 T1, Matériaux biodégradables pour l'agriculture et } \\
\text { l'horticulture-Produits de paillage-Exigences et méthodes d'essai }\end{array}$ & Biodegradation of mulch films in soil & $\begin{array}{l}\text { AFNOR AFNOR, La Plaine Saint-Denis Cedex, } \\
\text { France } 2005\end{array}$ \\
\hline $\begin{array}{l}\text { OK Biodegradable SOIL: Initial acceptance tests. Program OK } 10 . \\
\text { Bio-products-degradation in soil }\end{array}$ & Biodegradation in soil & $\begin{array}{l}\text { Certification Institute Vinçotte, Brussels, } \\
\text { Belgium }\end{array}$ \\
\hline $\begin{array}{l}\text { UNI 11183, Plastic materials biodegradable at ambient temperature. } \\
\text { Requirements and test methods }\end{array}$ & Home composting & UNI Ente Nazionale Italiano di Unificazione, Italy, \\
\hline $\begin{array}{l}\text { UNI 11355, Manufatti plastici biodegradabili in compostaggio } \\
\text { domestico-Requisiti e metodi di prova }\end{array}$ & Home composting & UNI Ente Nazionale Italiano di Unificazione, Italy \\
\hline $\begin{array}{l}\text { UNI } 11462 \text { Plastic materials biodegradable in soil-Types, requirements and } \\
\text { test methods }\end{array}$ & Biodegradation in soil & UNI Ente Nazionale Italiano di Unificazione, Italy \\
\hline UNI 11495, 2013 Biodegradable thermoplastic materials for use in & Biodegradation in soil & UNI Ente Nazionale Italiano di Unificazione, Italy \\
\hline
\end{tabular}
agriculture and horticulture.

Mulching films-Requirements and test methods 
TABLE 2 | Bio-tests for ecotoxicity considered by the different standards on biodegradable plastics and packaging.

\begin{tabular}{|c|c|c|}
\hline Standard & Matrix and dose of plastics & Test method \\
\hline $\begin{array}{l}\text { EN } 13432 \\
\text { EN } 14995 \\
\text { ISO } 17088 \\
\text { ISO18606 } \\
\text { ASTM D6400 }\end{array}$ & $\begin{array}{l}\text { Compost, after a 3-month } \\
\text { composting process with } \\
10 \% \text { plastics }\end{array}$ & $\begin{array}{l}\text { Assay with two plant species } \\
\text { described in the specific } \\
\text { Annex "Determination of } \\
\text { ecotoxic effects to higher } \\
\text { plants" based on the OECD } \\
208 .\end{array}$ \\
\hline $\begin{array}{l}\text { UNI } 11462 \\
\text { UNI } 11495 \\
\text { UNI } 11183 \\
\text { UNI } 11355\end{array}$ & $\begin{array}{l}\text { Soil, after a 3-month } \\
\text { incubation period with 1\% } \\
\text { plastics }\end{array}$ & $\begin{array}{l}\text { Determination of seed } \\
\text { germination and growth of } \\
\text { plants according to Annex K } \\
\text { and L, respectively, of UNI } \\
10780 \text {. } \\
\text { Acute toxicity on earthworms } \\
\text { according to ISO 11268-1. } \\
\text { Acute toxicity on Daphnia, } \\
\text { following ISO 6341, } 2012 \text {. }\end{array}$ \\
\hline $\begin{array}{l}\text { NF U 52-001 } \\
\text { T1 }\end{array}$ & $\begin{array}{l}\text { Soil, after a 90-day incubation } \\
\text { with an amount of mulch film } \\
\text { equivalent to the dose used in } \\
\text { field multiplied by a } \\
\text { multiplicative factor of } 100 \text {. } \\
\text { This corresponds to the mass } \\
\text { needed to cover } 1 \mathrm{~m}^{2} \text { of } \\
\text { product per } 300 \mathrm{~kg} \text { of dry soil }\end{array}$ & $\begin{array}{l}\text { Determination of seed } \\
\text { germination and growth of } \\
\text { plants according to ISO } \\
11269-2 \text {. } \\
\text { Acute toxicity on earthworms } \\
\text { FD X 31-251, } 1994 \text {. } \\
\text { Acute toxicity on algae NF T } \\
90-375,1998 \text {. }\end{array}$ \\
\hline $\begin{array}{l}\text { OK } \\
\text { Biodegradable } \\
\text { Soil }\end{array}$ & $\begin{array}{l}\text { Compost with a } 10 \% \\
\text { concentration of test material } \\
\text { or soil with a } 1 \% \\
\text { concentration of test material }\end{array}$ & As EN 13432. \\
\hline
\end{tabular}

standards, which can be considered as an indication of total biodegradation and of no remaining residues (De Wilde, 2014). Additionally, the ecotoxicity tests applied to the compost or to the soil after the biodegradation of the plastic, make sure that products of biodegradation do not affect environment.

However, due to the growing volumes of biodegradable polymers and plastics, interest in their environmental safety is increasing and more research is carried out (Kapanen, 2012). A strong concern of the public opinion is about the environmental impact of persistent substances possibly released during polymer biodegradation and composting which could subsequently be spread into the environment during fertilization with compost, or directly diffused during their biodegradation in soil. It is therefore of interest for all the stakeholders to extend the range of the applied ecotoxicity tests in order to dispel any doubt and assure a smooth development of this promising industrial sector. This is the reason why some attempt has been made to apply biotests, used in other sectors of environmental sciences, in the assessment of biodegradable plastics safety.

The so-called "Flash test," based on the kinetic measurement of bioluminescence by Vibrio fischeri, has been applied on compost (Tuominen et al., 2002) and on vermiculite (Degli-Innocenti et al., 2001) exposed to plastic materials. The conclusion of the studies was that the Flash test could be reliably used to verify the ecotoxicity of extracts from the biodegradation matrices (either vermiculite or compost).
A nitrification inhibition test was applied to soil extracts (Bettas Ardisson et al., 2014) after a biodegradation test based on the standard ISO 14238 (2012) for the measurement of nitrification activity. The conclusion was that the test approach was suitable for reaching conclusions on the effects of biodegradable plastics on soil.

No other biotests have been applied to our knowledge in this sector. The intention of this work was to verify the applicability of a larger number of bioassays for the determination of the potential ecotoxicity of soil after the biodegradation of plastics. In particular, the organisms included bacteria and protozoa (Vibrio fischeri and Dictyostelium discoideum, respectively), the green alga Pseudokirchneriella subcapitata, plants (the monocotyledon Sorghum saccharatum and the dicotyledon Lepidium sativum), and invertebrates animals (Daphnia magna, a freshwater crustacean, and the Oligochaeta earthworm Eisenia andrei). The array of ecotoxicological tests, including those routinely adopted by the Italian Institute for Protection and Environmental Research (ISPRA) and applied by territorial Environmental Agencies, was employed on soils where samples of biodegradable plastics had been biodegraded for 6 months. These tests are based on the OECD Guidelines or on other recognized protocols.

\section{MATERIALS AND METHODS}

\section{Test Material}

The test materials were three Mater-Bi plastic films provided by Novamont S.p.A.: Mater-Bi DF04A (internal denomination RIC 1362); Mater-Bi EF04P (internal denomination RIC 1619), Mater-Bi AF05S0 (internal denomination RIC 1620). These materials are biodegradable and compostable plastics, tested according the European standard EN13432 (Packaging. Requirements for packaging recoverable through composting and biodegradation. Test scheme and evaluation criteria for the final acceptance of packaging). They are based on the following constituents: corn starch; bio-based aliphatic polyester; biobased aliphatic- aromatic copolyester; natural plasticisers. The elemental composition and the concentration of regulated metals is shown in Tables 3, 4 (source: Novamont). The films were powdered by means of cryogenic grinding with liquid nitrogen using an IKA M20 grinder.

\section{Reference Material}

The reference material was pure micro-crystalline cellulose (Merck) in powder.

\section{Soil}

The standard soil was prepared and supplemented as described in Table 5, following the ISO 17556 (2012). The water content was adjusted by adding deionized water in order to reach a total holding capacity between 40 and $60 \%$. The final water content of wet soil used in the experiment was $16.9 \%$.

The total solids were determined after drying in an oven at $105^{\circ} \mathrm{C}$ until constant weight was achieved. The volatile solids were determined after calcination at $550^{\circ} \mathrm{C}$ until constant weight was achieved. The $\mathrm{pH}$ was determined by diluting the soil in distilled water. A $10 \mathrm{~g}$ sample of soil was mixed with $25 \mathrm{ml}$ of 
TABLE 3 | Mater-Bi elemental composition.

\begin{tabular}{lccc}
\hline Material & Carbon (\%) & Hydrogen (\%) & Nitrogen (\%) \\
\hline DF04A (internal code RIC 1362) & 59.35 & 6.98 & $<0.1$ \\
EF04P (internal code RIC1619) & 57.91 & 6.76 & $<0.1$ \\
AF05SO (internale code RIC 1620) & 58.85 & 7.04 & $<0.1$ \\
\hline
\end{tabular}

TABLE 4 | Concentration of regulated metals in Mater-Bi materials.

\begin{tabular}{lccc}
\hline Element & $\begin{array}{c}\text { AF05S0 (internal } \\
\text { code RIC 1620) } \\
\text { ppm }\end{array}$ & $\begin{array}{c}\text { EF04P (internal } \\
\text { code RIC1619) }\end{array}$ & $\begin{array}{c}\text { DF04A (internal } \\
\text { code RIC 1362) } \\
\text { ppm }\end{array}$ \\
\hline $\mathrm{As}$ & $<2$ & $<2$ & $<2$ \\
$\mathrm{Cd}$ & $<0.5$ & $<0.5$ & $<0.5$ \\
$\mathrm{Cr}$ & $<1$ & $<1$ & $<1$ \\
$\mathrm{~F}$ & $<100$ & $<100$ & $<100$ \\
$\mathrm{Hg}$ & $<0.25$ & $<1$ & $<0.25$ \\
$\mathrm{Mb}$ & $<1$ & $<2$ & $<1$ \\
$\mathrm{Ni}$ & $<2$ & $<5$ & $<2$ \\
$\mathrm{~Pb}$ & $<5$ & $<2$ & $<5$ \\
$\mathrm{Cu}$ & $<2$ & $<0.75$ & $<2$ \\
$\mathrm{Se}$ & $<10$ & $<0.75$ \\
$\mathrm{Zn}$ & $<10$ & $<10$ & $<10$ \\
\hline
\end{tabular}

TABLE 5 | Preparation of one Kg (dry) of standard soil.

\begin{tabular}{|c|c|}
\hline Constituent & Grams \\
\hline Industrial quartz sand & 700 \\
\hline Clay & 100 \\
\hline Natural soil screened $<5 \mathrm{~mm}^{\mathrm{a}}$ & 160 \\
\hline Mature compost screened $<5 \mathrm{~mm}$ with a $50 \%$ water content & 40 \\
\hline $\mathrm{KH}_{2} \mathrm{PO}_{4}$ & 0.2 \\
\hline $\mathrm{MgSO}_{4}$ & 0.1 \\
\hline $\mathrm{NaNO}_{3}$ & 0.4 \\
\hline Urea & 0.2 \\
\hline $\mathrm{NH}_{4} \mathrm{Cl}$ & 0.4 \\
\hline
\end{tabular}

${ }^{a}$ The soil was collected from an agricultural field at the Centro Sperimentazione ed Assistenza Agricola (CeRSAA) in Albenga (Italy). The soil is routinely analyzed by CeRSAA and has a $\mathrm{C} / \mathrm{N}$ ratio of 9.2 .

deionized water, stirred for $15 \mathrm{~min}$ and left unstirred for $30 \mathrm{~min}$ before measuring the $\mathrm{pH}$ with a Hanna Instruments $\mathrm{pH}$ meter model pH 211 (Violante and Adamo, 2000).

According to ISO 17556 (2012), the $\mathrm{pH}$ of the inoculum should be between 6 and 8 and the $\mathrm{C} / \mathrm{N}$ ratio should be at least 40:1. Both conditions were met.

\section{Soil Incubation}

Fifteen 3-L glass flasks were each filled with a $800.0 \mathrm{~g}$ sample of soil. Three flasks were supplemented with $10.0 \mathrm{~g}$ of RIC 1362; three flasks were supplemented with $10.0 \mathrm{~g}$ of RIC 1619; three flasks were supplemented with $10.0 \mathrm{~g}$ of RIC 1620; three flasks were supplemented with $10.0 \mathrm{~g}$ of cellulose; three flasks were not supplemented (control soil). Each flask was carefully mixed with a spatula in order to mingle soil and test material and then incubated at $28^{\circ} \mathrm{C} \pm 2{ }^{\circ} \mathrm{C}$. Pressurized air was sent over a gas flow controller and an air flow rate of about $6 \mathrm{~L} / \mathrm{h}$ was supplied at the bottom of each reactor (dynamic conditions). The incubation lasted 6 months. The soil of each reactor was mixed at regular intervals and the water content was maintained constant by adding deionized water during the incubation period. The soil replicates were analyzed separately in ecotoxicity tests.

\section{Ecotoxicological Analysis}

Soils (elutriates and whole soil) were analyzed applying a set of acute and chronic bioassays with bacteria, protozoa, algae, plants, crustaceans, and earthworms. In addition to the control soil (i.e., soil without Mater-Bi/cellulose degradation products), it was also used a (negative) lab control that allowed to demonstrate the normal state of the animals, and to verify the good quality of the control soil (Wallace Hayes and Kruger, 2014). The characteristics of the lab controls are specified in the standardized methodologies and reported here in the description of the different bioassays. Elutriates were obtained by diluting each soil sample with 3 parts of deionized water (dilution 1: $4 \mathrm{w} / \mathrm{v}$ ). A volume of $300 \mathrm{ml}$ of water was added to $100 \mathrm{~g}$ of soil (dry weight) in a $500 \mathrm{ml}$ glass jars. The samples were subjected to continuous stirring (about $170 \mathrm{rpm}$ ) for $60 \mathrm{~min}$ and allowed to settle for $24 \mathrm{~h}$ at $4^{\circ} \mathrm{C}$. Subsequently, the liquid phase (water extract) was centrifuged at $4000 \mathrm{rpm}$ at $4^{\circ} \mathrm{C}$ for $15 \mathrm{~min}$ and filtered with a $0.45 \mu \mathrm{m}$ filter in order to obtain a clear solution. The water extracts (elutriates) thus obtained were used for following testing.

\section{V. fischeri Bioluminescence Inhibition (Microtox ${ }^{\circledR}$ ) Test}

The bioassay with the luminescent bacterium $V$. fischeri was performed following the standard ISO 11348-3 (2007) [Water quality-determination of the inhibitory effect of water samples on the light emission of $V$. fischeri (luminescent bacteria test)part 3: method using freeze-dried bacteria]. The reduction of light emitted by bacteria after exposure for $15 \mathrm{~min}$ to elutriate samples was measured with a Microtox ${ }^{\circledR}$ luminometer detecting the light intensity at $490 \mathrm{~nm}$, the wavelength emitted by the bacteria. The test requires the use of a lab control $(2 \% \mathrm{NaCl}$ in Milli-Q water), as well a positive control consisting of a 3,5-dichlorophenol $\left(\mathrm{C}_{6} \mathrm{H}_{4} \mathrm{Cl}_{2} \mathrm{O}\right)$ solution $(6 \mathrm{mg} / \mathrm{L})$. The test is considered valid if the bioluminescence inhibition induced in organisms exposed to the positive control is $\geq 50 \%$.

\section{D. discoideum}

The amoebic cells of $D$. discoideum (AX-2 strain) were cultured as described by Watts and Ashworth (1970), until their concentration reached $2-4 \times 10^{6}$ cells $/ \mathrm{mL}$. After centrifugation, the cells $\left(0.75 \times 10^{6}\right.$ cells $\left./ \mathrm{mL}\right)$ were incubated for 3 and $24 \mathrm{~h}$ in the elutriate samples (25\% AX-2 medium with $50 \mu \mathrm{M} \mathrm{CaCl}$ and $10 \mu \mathrm{g} / \mathrm{mL}$ tetracycline) as well in the lab control (25\% AX2 medium and 75\% Page's Amoeba Saline with $50 \mu \mathrm{M} \mathrm{CaCl} \mathrm{Cl}_{2}$ and $10 \mu \mathrm{g} / \mathrm{mL}$ tetracycline) for the evaluation of vitality and reproduction rate, respectively.

Cell viability was evaluated essentially as described by Dondero et al. (2006), incubating the cells with SYBR Green ${ }^{\mathrm{TM}}$ 
(Invitrogen Molecular Probes, Eugene, OR, USA), that in alive amoebae is a cell membrane impermeable DNA-binding dye; cells were observed at $200 \times$ magnification (Zeiss Axiovert $100 \mathrm{M}$ ) using a FITC emission filter and transmission light simultaneously, a combination allowing a clear discrimination of dead cells (cells with a brightly fluorescent nucleus) from alive cells (with still intact biological membranes). For the reproduction rate, cells were counted with the use of a hemocytometer chamber (Bürker) (Dondero et al., 2006).

\section{Seed Germination}

The determination of the inhibition of germination was conducted following the method UNICHIM N. 1651 (2003), using seeds of sorghum (S. saccharatum), a monocotyledon plant species, and of cress (L. sativum), a dicotyledonous species.

Before the test, the seeds were soaked with distilled water and left in agitation for $40 \mathrm{~min}$. An amount of $10 \mathrm{~g}$ (dry weight) of soil, for each sample, was placed in a Petri dish $(90 \mathrm{~cm}$ diameter) and a about $6.5 \mathrm{ml}$ of distilled water. A filter paper Whatman \#1 was then positioned on the wet soil and on this 10 seeds per plate. The plates were incubated for $72 \mathrm{~h}$ in the dark at a temperature of $25 \pm 2{ }^{\circ} \mathrm{C}$. Quartz sand was used as lab control. Two replicates were set up for each sample of soil (replication) and for each plant species for a total of six replicates for each tested soil. After incubation the germinated seeds were counted (with root length $\geq 1 \mathrm{~mm}$ ) and the results expressed as \% of sprouted seeds. The test is considered valid if, at the end of the incubation period, the seed germination in the lab control is $>90 \%$.

\section{P. subcapitata Growth Inhibition Test}

The green algal bioassay was performed following the standard ISO 8692, 2004 (Water quality-freshwater algal growth inhibition test with unicellular green algae). Algal cultures in exponential growth phase were used $\left(1 \times 10^{6}\right.$ cells $\left./ \mathrm{mL}\right)$. Growth inhibition was measured after exposure to elutriate samples for $72 \mathrm{~h}$ using a cell counting chamber (Bürker). The test requires the use of a standard solution (ISO 8692, 2004) as a lab control; the cell density after $72 \mathrm{~h}$ of incubation in the lab control has to be at least 67 times higher than the initial concentration $(1 \times$ $10^{4}$ cells $/ \mathrm{mL}$ ) so that the test to be valid.

\section{D. magna Immobilization Test and Reproduction}

The acute crustacean bioassay was performed following the standard ISO 6341 (2012) [Water quality-determination of the inhibition of the mobility of D. magna Straus (Cladocera, Crustacea)-acute toxicity test]. In the experiments, neonates $<24 \mathrm{~h}$ old were exposed to elutriate samples for $24 \mathrm{~h}$ at $20 \pm 2{ }^{\circ} \mathrm{C}$, with a $16 / 8 \mathrm{~h}$ light-dark cycle. As laboratory control, we used a standard solution (ISO 6341, 2012). At the end of the period of exposure, the test containers were subjected to gentle agitation and the organisms immobilized, i.e., those animals not able to swim within $15 \mathrm{~s}$, were counted. The test is valid if, in the lab control, the immobilized organisms are $<10 \%$.

The chronic test was carried out in ventilated crystallizers testing neonates $<24 \mathrm{~h}$ old per tested soil, following the indications of OECD (2012). Each daphnid, individually held, was fed with $1 \mu \mathrm{l}$ of algal cells of $P$. subcapitata $\left(1 \times 10^{8}\right.$ cells / $\mathrm{ml})$ per day. Each sample was topped up every 7 days with water extract/control water. The incubation, for the chronic assay, was conducted for 21 days under the conditions described above, at the end of which the rate of parental vitality and the total number of living offspring (counted and removed daily from the crystallizers) generated from each parent. The chronic test is considered valid if, after 21 days of exposure, in the lab control parental mortality does not exceed $20 \%$.

\section{E. andrei}

\section{Animals}

E. andrei earthworms (Bouché, 1972) were cultured as described in the OECD guidelines (OECD, 2004). Organisms were selected from a synchronized culture with a homogeneous age structure. Adult worms with clitellum of similar size and weight (400$500 \mathrm{mg}$ ) were utilized in the experiments.

\section{Exposure to Soil Samples}

For each soil replicate, ten worms were kept in $500 \mathrm{~g}$ of soil placed in glass test containers (OECD, 2004). At least three replicates per soil sample were used. The test containers were maintained in a climate-controlled chamber at $20 \pm 1^{\circ} \mathrm{C}$ and maintained under controlled light-dark cycles ( $16 \mathrm{~h}$ light, $8 \mathrm{~h}$ dark) with illumination of $800 \mathrm{~lx}$ for a period of $28 \mathrm{~d}$.

At the end of the 4 weeks of incubation the living adult worms and cocoons were removed from the test vessels and counted. The cocoons were repositioned in soil samples and incubated for further 28 days under the same conditions. At the end of the second incubation period, the number of juveniles hatched from the cocoons were recorded.

\section{RESULTS}

The soils after biodegradation of three Mater-Bi plastic films (i.e., RIC 1362, RIC 1619, and RIC 1620-see Section Materials and Methods), named for simplicity "Mater-Bi soil," of cellulose ("cellulose soil") and the control soil were all tested in parallel.

The results concerning the possible toxicity of the Mater-Bi soils and cellulose soils on Bacteria and Protists are reported in Figures 1, 2. All the elutriates obtained from the MaterBi soils and cellulose soils stimulated the light emission of the bacterium $V$. fischeri when compared with the lab control, although the enhancement never reach the value $+20 \%$ indicative of a biostimulation effect (Figure 1). However, no changes were observed among the values from the control soil and Mater-Bi soils or cellulose soil.

Figure 2 shows the effects of the Mater-Bi soils and cellulose soil on the survival and reproduction rate of the social amoeba D. discoideum. The elutriates did not cause negative effects on the survival of the organisms (Figure 2A) but induced a slight decrease of the reproduction rate (Figure 2B). Such decrease was significant, with respect to lab control, for the amebae exposed to the elutriates of the soil RIC 1620 (Mater-Bi containing soil) and of the cellulose soil; however, the effects never reach the decrease of $20 \%$ with respect to the lab controls, a value usually considered as an indication of weak toxicity. 


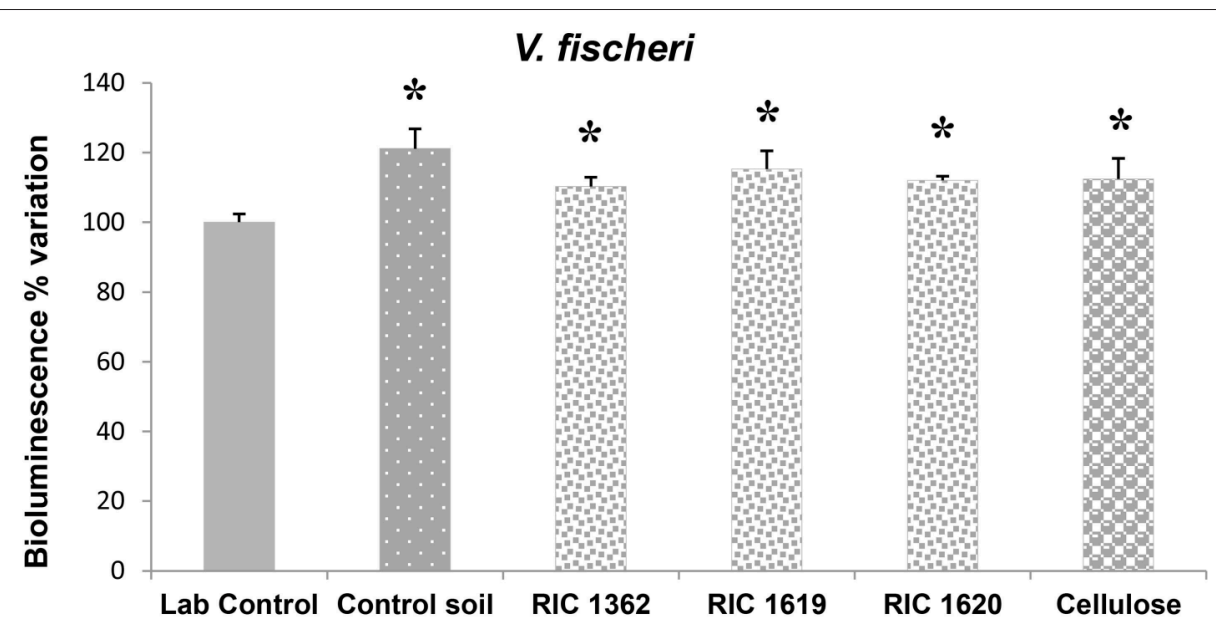

FIGURE 1 | Light emission of $\boldsymbol{V}$. fischeri after exposure to the elutriate samples. Data are expressed as \% variation with respect to lab control and represent the mean \pm SD of at least five replicates. *Indicates statistically significant differences with respect to lab control values $(p<0.05 \mathrm{Mann}-\mathrm{Whitney} \mathrm{U}$-test). RIC 1362 , RIC 1619, RIC 1620, Mater-Bi soils; Cellulose, soil containing cellulose reference material.
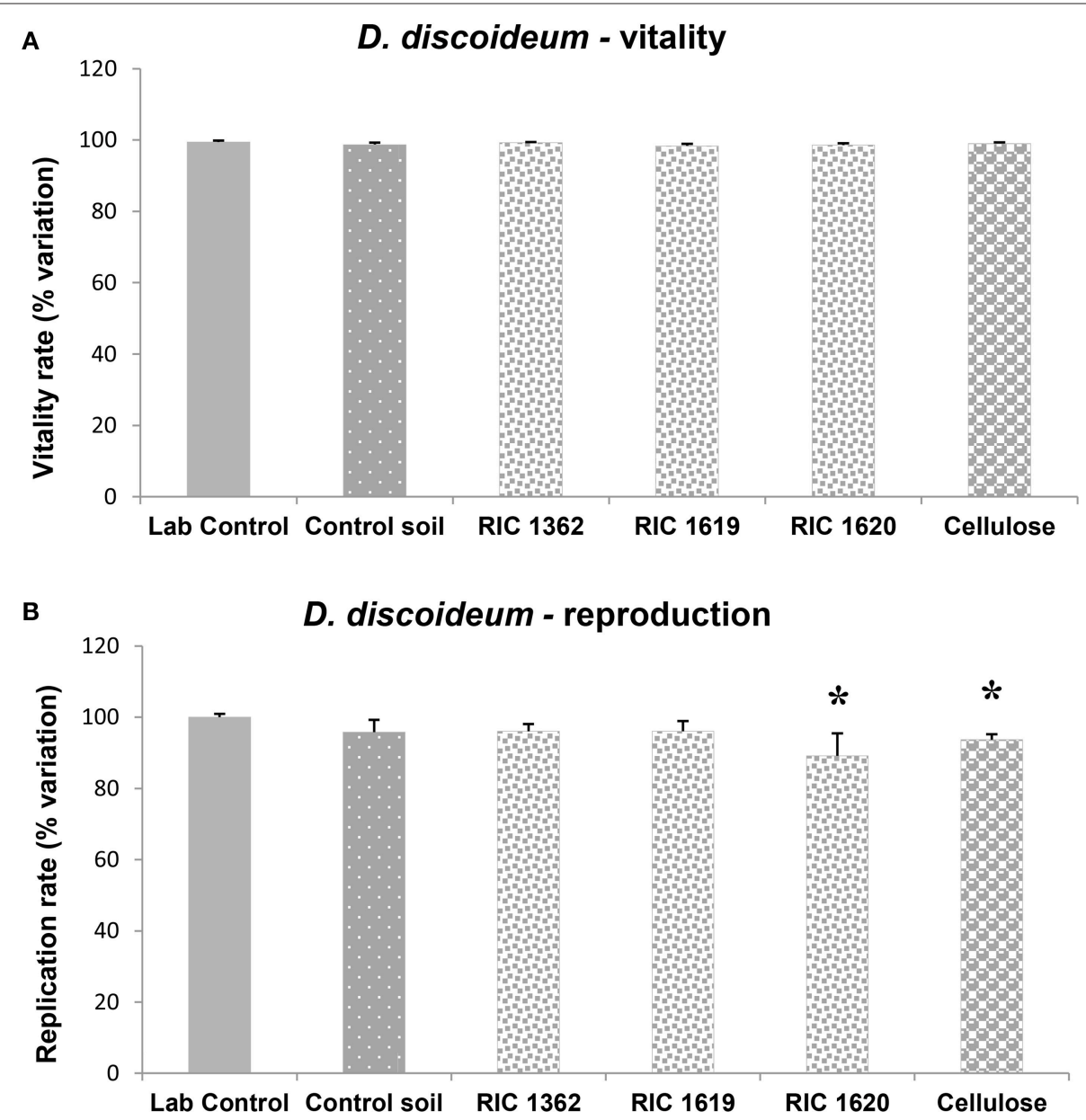

FIGURE 2 | Survival (A) and reproduction rate (B) of D. discoideum amoebae after exposure to the elutriate samples. Data, expressed as \% variation (A) and $\%$ variation with respect to lab control (B), represent the mean \pm SD of at least five replicates. *Indicates statistically significant differences with respect to lab control values ( $p$ < 0.05 Mann-Whitney U-test). RIC 1362, RIC 1619, RIC 1620, Mater-Bi soils; Cellulose, soil containing cellulose reference material. 
The results presented in Figures 3-5 concern the evaluation of the possible effects of Mater-Bi and cellulose soils on autotrophic organisms.

The data related to the effects on a monocotyledon $S$. saccharatum and the dicotyledon $L$. sativum demonstrate that the seeds of both plants correctly germinate in the Mater-Bi soils and cellulose soils without differences in the germination rate with respect to the control soil or lab controls (Figures 3, 4).

In the same way, when the alga P. subcapitata was growth for $72 \mathrm{~h}$ in the elutriates obtained from the different soils no negative effects were observed on its replication rate (Figure 5).

Figure 6 shows the results of the acute and chronic toxicity tests using D. magna as model organism. The data reported in Figure 6A clearly demonstrate that there were no effects on the motility rate of the organisms after $24 \mathrm{~h}$ of exposure to the elutriate containing the Mater-Bi and cellulose soils. These results were confirmed by the data on the effects of the elutriate on the reproduction rate of $D$. magna (Figure 6B): no effects were found in organisms exposed to the elutriates from Mater-Bi soils; however, the elutriates containing cellulose soils determine an increase in the reproduction rate of this cladoceran, although in very variable extent.

Finally, in Figures 7, 8 are reported the results concerning the exposure of the earthworm E. andrei to the Mater-Bi soils and cellulose soils. The results obtained in earthworms exposed to the control soil were comparable to an standardized artificial soil (OECD, 2004) during the period of exposure (data not shown).

The data demonstrate that there are no toxic effects of the studied soils on the survival rate of worms (Figure 7). Data concerning the number of the cocoons produced (Figure 8A) and the value of the number of juveniles earthworms (Figure 8B) demonstrate that the reproduction rate (Figure $\mathbf{8 C}$ ) is similar to the value observed in the animals maintained in the control soil.

\section{S. saccharatum}

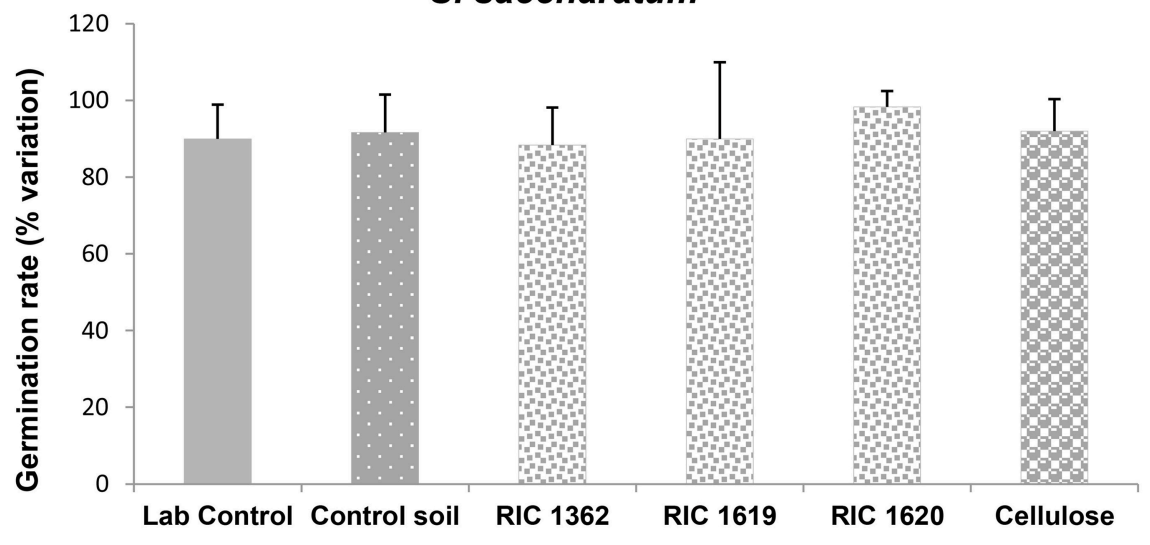

FIGURE 3 | Germination of S. saccharatum after exposure to the soil samples. Data are expressed as \% variation and represent the mean \pm SD of at least five replicates. *Indicates statistically significant differences with respect to lab control values ( $p<0.05$ Mann-Whitney U-test). RIC 1362, RIC 1619, RIC 1620, Mater-Bi soils; Cellulose, soil containing cellulose reference material.

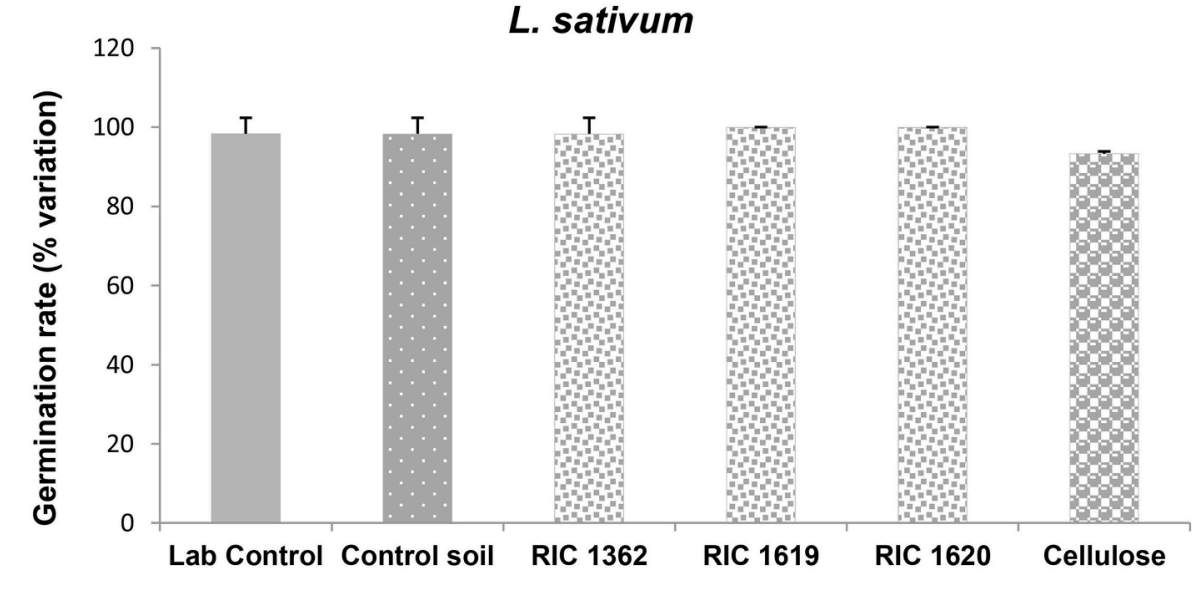

FIGURE 4 | Germination of $\boldsymbol{L}$. sativum after exposure to the soil samples. Data are expressed as \% variation and represent the mean \pm SD of at least five replicates. *Indicates statistically significant differences with respect to lab control values ( $p<0.05$ Mann-Whitney U-test). RIC 1362, RIC 1619, RIC 1620, Mater-Bi soils; Cellulose, soil containing cellulose reference material. 


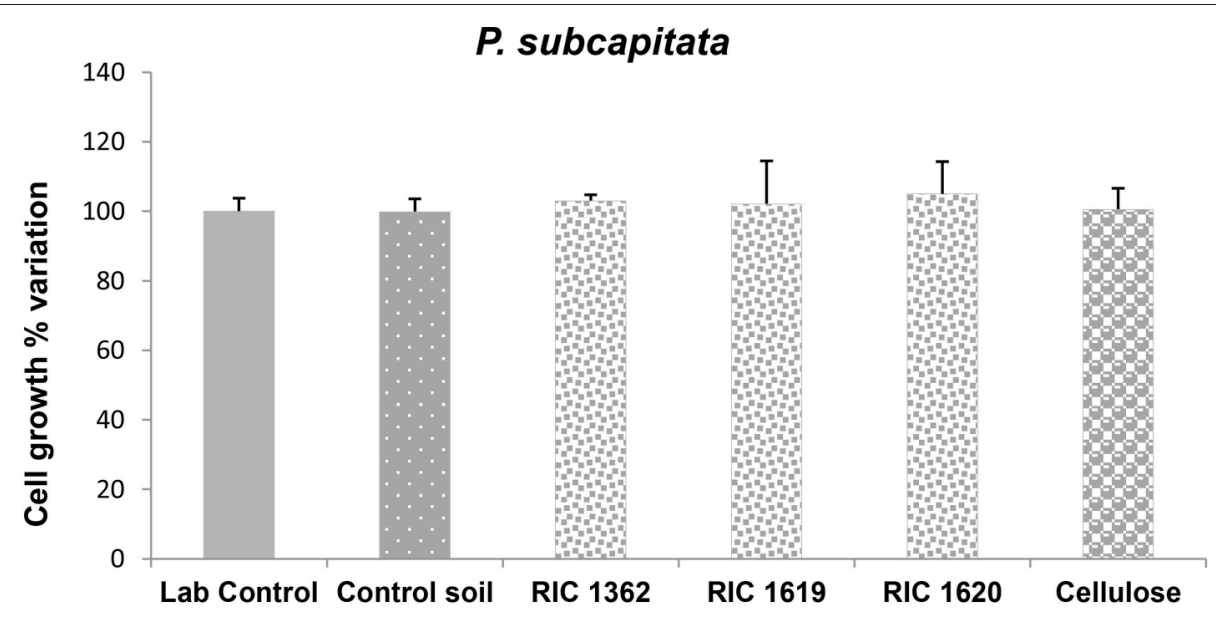

FIGURE 5 | Growth of the alga $P$. subcapitata after exposure to the elutriate samples. Data are expressed as \% variation with respect to lab control and represent the mean $\pm S D$ of at least five replicates. ${ }^{*}$ Indicates statistically significant differences with respect to lab control values $(p<0.05$ Mann-Whitney $U$-test). RIC 1362, RIC 1619, RIC 1620, Mater-Bi soils; Cellulose, soil containing cellulose reference material.
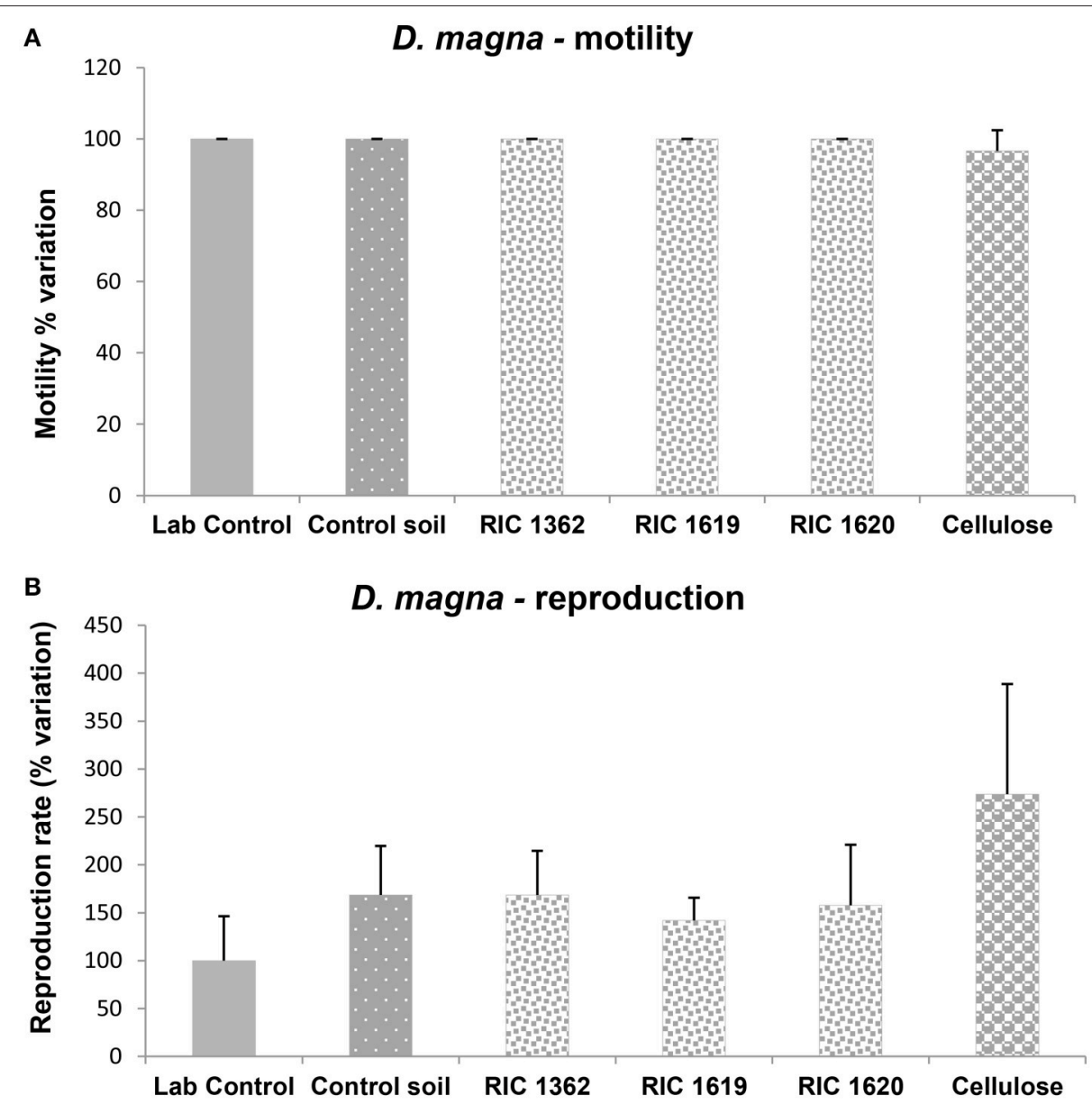

FIGURE 6 | Motility (A) and reproduction (B) of $\boldsymbol{D}$. magna after exposure to the elutriate samples. Data, expressed as $\%$ variation (A) and $\%$ variation with respect to lab control (B), represent the mean \pm SD of at least five replicates. ${ }^{*}$ Indicates statistically significant differences with respect to lab control values $(p<0.05$ Mann-Whitney U-test). RIC 1362, RIC 1619, RIC 1620, Mater-Bi soils; Cellulose, soil containing cellulose reference material. 


\section{E. andrei - vitality}

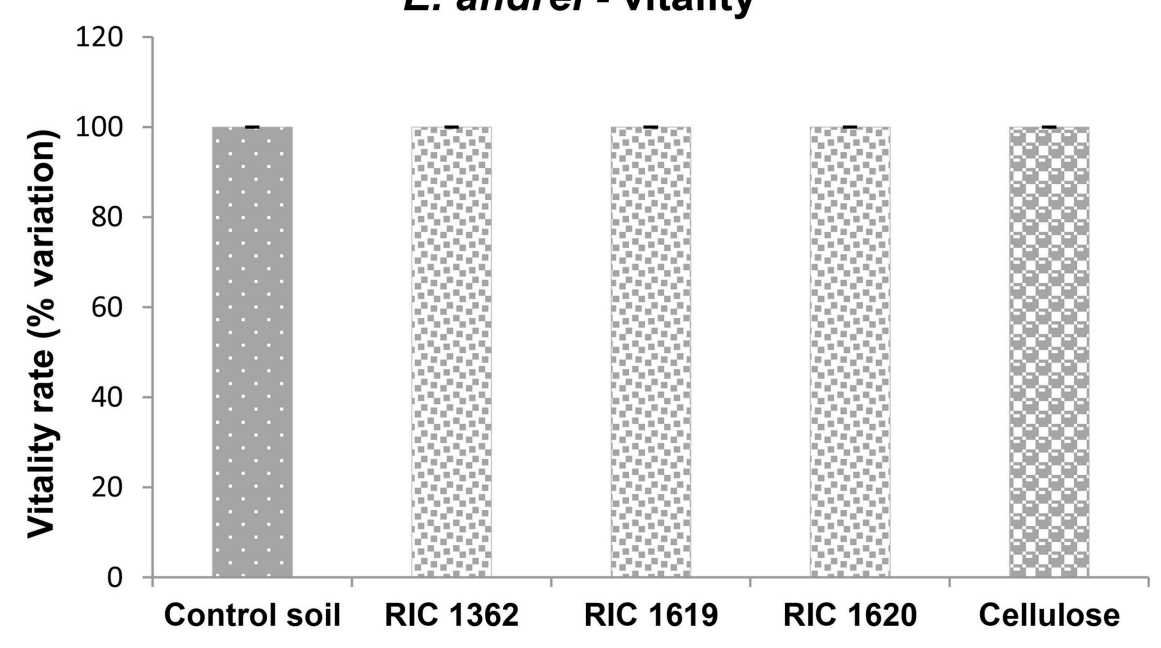

FIGURE 7 | Effects on vitality of the oligochaete $\boldsymbol{E}$. andrei exposed to the soil samples. Data are expressed as $\%$ variation and represent the mean \pm SD of at least three replicates. *Indicates statistically significant differences with respect to control values ( $p<0.05$ Mann-Whitney U-test). RIC 1362, RIC 1619, RIC 1620,

Mater-Bi soils; Cellulose, soil containing cellulose reference material.

\section{DISCUSSION}

Plastic contamination of terrestrial and aquatic ecosystems is nowadays considered one of the major environmental issues. In fact, the plastic global production was about 299 million tons in 2013 (PlasticsEurope, 2015) and while efforts to proper recovery and recycling are increasing still a fraction of plastic waste is not recovered and represents a contamination to some environments (UNEP, 2014). Due to the important role of plastic products in our society, in the last two decades different biodegradable plastics were produced with the aim to substitute, at least in part, the plastic products; this, together with a substantial effort toward recovery and recycling, should allow to reduce the negative environmental effects due to plastic waste accumulation in the different ecosystems (World Economic Forum, 2016).

However, not all the biodegradable plastics are "environmental friendly" and this depends on their chemical composition: in some case it was found that degradable plastics were toxic for edaphic and/or aquatic organisms (Fritz, 2014), thus their use no giving all the expected environmental advantages. In particular, few studies have been devoted to investigate the possible biological effects of plastic degradation products in organisms characteristic of the different trophic levels in the food chains of the edaphic and aquatic ecosystems.

In this research, the environmental compatibility of the biodegradable plastic Mater-Bi was studied evaluating the potential toxicity of its degradation products on a wide range of model organisms using well known standardized guidelines or, in some cases, scientific literature protocols.

Mater-Bi is a plastic material based on corn starch and biodegradable polyesters widely used for package (Bastioli, 2005). Same Mater-Bi grades are certified as "OK Biodegradable Soil" by Vinçotte (Belgium). The certification programme established by Vinçotte requires a biodegradation level of more than $90 \%$ after 2 years in soils (under controlled physical-chemical and microbiological conditions) and no ecotoxicity in soil exposed to the test material.

Ecotoxicity is assessed in soil samples after degradation of the plastic material introduced at high concentration in comparison with control soils. The ecotoxicity test is a seedling and plant growth test based on the OECD 208 (OECD, 2006) standard test method.

These characteristics have encouraged a wider employ of this biodegradable plastic also for other uses such as in the agricultural field as mulch films (Kyrikou and Briassoulis, 2007).

For this reasons it was considered of great importance to clarify the possible toxicity of this new biodegradable plastic with a larger array of biotests.

With the aim to clarify this important aspect, Mater-Bi was degraded in soils under controlled conditions for 6 months at a $1 \%$ concentration, following the Vinçotte certification programme testing scheme.

The selected model organisms for the evaluation of soil quality were bacteria and protozoa ( $V$. fischeri and D. discoideum, respectively), the green alga $P$. subcapitata, plants such as the monocotyledon $S$. saccharatum and the dicotyledon L. sativum, and invertebrates animals such as the D. magna, a freshwater crustacean, and the Oligochaeta earthworm E. andrei.

The ecotoxicological tests on the alga and plants demonstrated that the Mater-Bi biodegradation products are not harmful for these autotrophic organisms. It should be noted that a large part of the bioassays used are chronic tests i.e., the more sensitive at organism level.

Similarly, no effects were found when the soil toxicity was evaluated using as model organisms two invertebrates such as D. magna and the earthworm E. andrei: also in this case the endpoints evaluated, both mortality (acute toxicity) and 


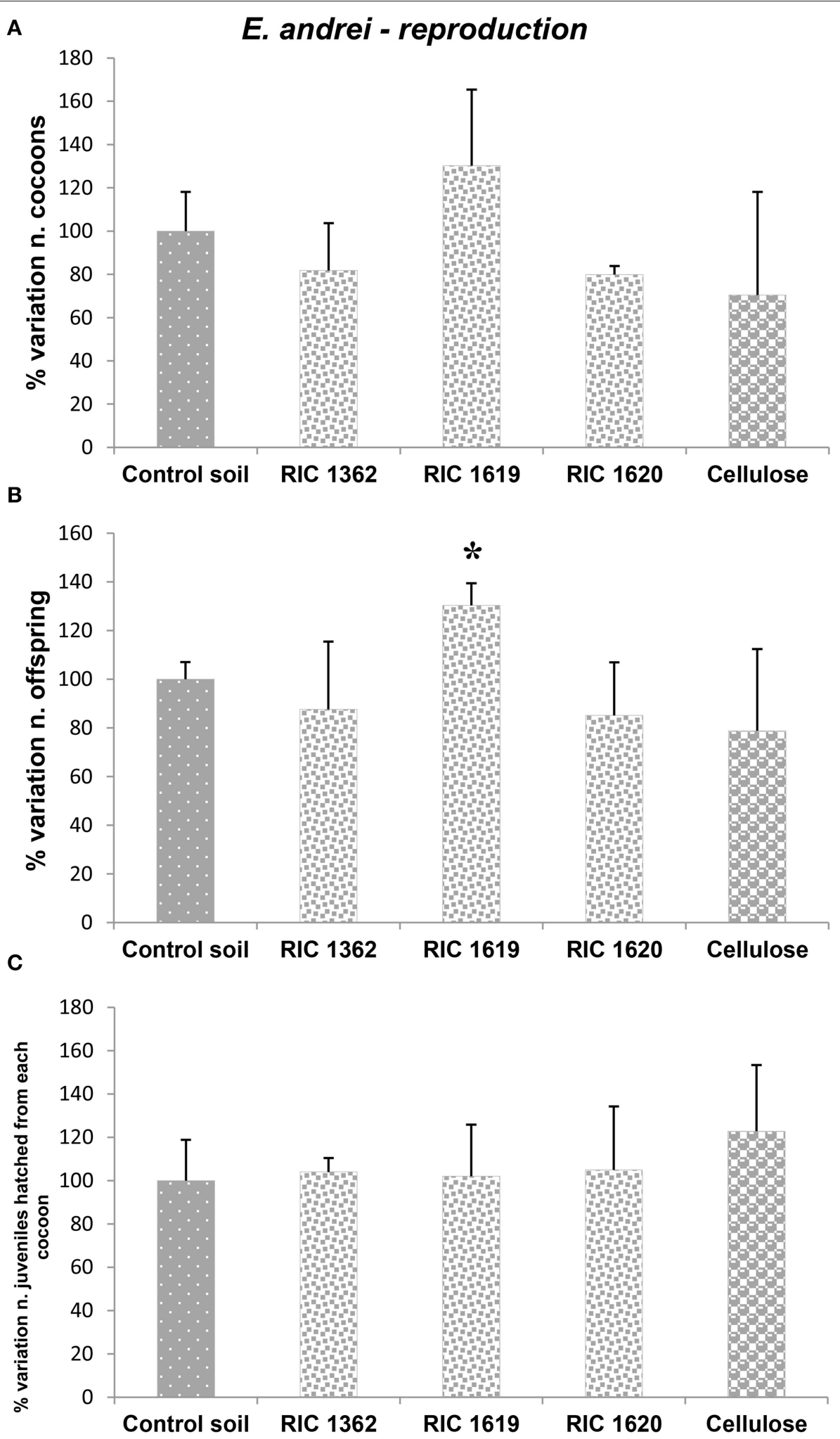

FIGURE 8 | Effects on reproduction of the oligochaete E. andrei exposed to the soil samples: (A) cocoons; (B) offspring; (C) number of juveniles hatched from each cocoon. Data are expressed as \% variation with respect to soil control and represent the mean \pm SD of at least three replicates. *Indicates statistically significant differences with respect to control values ( $p<0.05$ Mann-Whitney U-test). RIC 1362, RIC 1619, RIC 1620, Mater-Bi soils; Cellulose, soil containing cellulose reference material. 
reproduction (chronic toxicity) ensured the higher sensitivity of the employed bioassays.

The data concerning the possible effects of the plastic degradation products on the bacterium $V$. fischeri using the Microtox test indicated that there are no negative effects on these organisms. These results are in line with previously reported data indicating that the Mater-Bi degradation products in soils do not affect the nitrification process depending on the microbiological activity (Bettas Ardisson et al., 2014).

Finally, an extremely sensitive bioassay using as model organism the social amoeba $D$. discoideum was used. This amoeba lives in the soil pore water and it is cultivated in lab in an aqueous medium. This ecotoxicological test is therefore adequate to study the biological effects of contaminants present in the soil using the elutriate extracts. This test was found to be more sensitive than the classical bioassays used by the environmental agencies as demonstrated in previous studies devoted to investigate the toxicity of waters and sediments of a freshwater ecosystem (Sforzini et al., 2008). Our results demonstrated no effects on the survival rate of the protozoa but the chronic test on the reproduction, that in $24 \mathrm{~h}$ analyses the second/third amoebae generation, shown a slight decrease up to $10 \%$ with respect to controls, a value that, being lower than $20 \%$, is not usually considered an indication of toxicity.

The variability of the data observed in some biotests (in particular in the reproduction tests of D. magna and E. andrei) should suggest to use more replicates in future application of these bioassays to biodegradable plastics testing.

Altogether, the data obtained in this study demonstrate that the soils exposed to high amount of Mater-Bi have no noxious effects on edaphic organisms; in particular, mono and dicotyledon plants results, indicate that Mater-Bi plastic products are innocuous for agricultural uses. It should be noted that the bioassay using as model organism the earthworm E. andrei is a $28 \mathrm{~d}$ test for the evaluation of the survival rate but it lasts $56 \mathrm{~d}$ when the endpoint is the reproduction. This latter chronic test evaluates the number of cocoons produced but also the number of newborn worms that develop in the soils; this ecotoxicological test has proved to be sensitive to the effects of low concentrations of different toxic chemicals (Van Gestel et al., 1992; Spurgeon et al., 1994). The use of this test confirmed that Mater-Bi degradation poses no risk for edaphic biodiversity.

In this study, we have used four bioassays for aquatic model organisms i.e., bacteria, algae, protozoa, and crustacean. The elutriates obtained from the Mater-Bi soils were no toxic for the organisms used for freshwater ecotoxicological analysis: these results are of great relevance from an ecotoxicological point of view. In fact, these data indicate that there is no risk that toxic chemicals possibly released during plastic degradation may contaminate surficial or underground waters with the consequence to enlarge the environmental problems.

The importance to use an adequate control for the different bioassays should be also emphasized. It appears relevant to associate to the usual "lab control" and to the control soil without plastic item an additional control soil in which an amount of a natural, no toxic product with a composition similar to the bioplastics is added to the sample. In this case cellulose, a sugar polymer, sharing similar molecular characteristics with Mater$\mathrm{Bi}$, a bioplastic with a relatively high biodegradability, and sugar content due to the presence of starch. This cellulose sample could show some differences from the control due to the high amount of nutrient compounds (in this case sugar) added to the matrix. It is known that eutrophic conditions could cause negative effects directly to the different model organisms used in the tests. Moreover, the excess of sugar and other nutrients in the soils may change, during the experiment, the structure of the community, that may alter the survival/reproductive capacity of a particular organism. Our study demonstrates that when limited changes in the performance of the organisms exposed to Mater-Bi soils were found, these effects were similarly observed in the organisms exposed to the soil added with cellulose.

\section{CONCLUSIONS}

When considered altogether these data suggest that the ecotoxicological approach used in this study could represent a standard for future investigation on the environmental impact of plastic degradation products by means of (i) the use of a standardized, detailed protocol for bioplastic degradation, (ii) the evaluation of a large battery of ecotoxicological tests using acute and chronic endpoints, (iii) the use of microorganisms, plants, and animals, (iv) the use of model organisms suitable to test the toxicity of soils and elutriates following international accepted protocols. These rules adopted in this study may represent the basis for the lab analysis of the environmental compatibility of new bioplastics and other biotechnological materials.

The results reported in this study demonstrate that Mater-Bi is a bioplastic that seems to meet an adequate standard of environmental safety. Although a large battery of ecotoxicological tests, using both acute and chronic end points, was used no noxious effect was found. The use of model organisms typical of soil and freshwater allows us to exclude possible negative effects on the biodiversity of the edaphic ecosystem and of the related freshwater (both groundwater and surficial) compartments.

\section{AUTHOR CONTRIBUTIONS}

SS was the responsible of the research activity and expert of soil ecotoxicological tests; LO was the responsible of the freshwater ecotoxicological tests; SC supported the different aspects of the research activity i.e., from soil and elutriate preparation to the test performance; AV was the research coordinator.

\section{ACKNOWLEDGMENTS}

This study was supported financially by a Novamont research grant (10/09/2014). 


\section{REFERENCES}

Bastioli, C. (2005). "Mater-Bi: biodegradable material for various applications," in Biopolymers On Line (Wiley-VCH Verlag GmbH \& Co. KGaA.), 10. doi: 10.1002/3527600035.bpola005

Bettas Ardisson, G., Tosin, M., Barbale, M., and Degli-Innocenti, F. (2014). Biodegradation of plastics in soil and effects on nitrification activity. A laboratory approach. Front. Microbiol. 5:710. doi: 10.3389/fmicb.2014.00710

Bouché, M. B. (1972). Lombriciens de France, Écologie et Systématique. Annales de Zoologie-Écologie animale. Paris: I.N.R.A. Publication.

De Wilde, B. (2014). "International and national norms on biodegradability and certification procedures," in Handbook of Biodegradable Polymers, 2nd Edn., ed C. Bastioli (Shrewsbury: Smithers Rapra Shawbury), 139-174.

Degli-Innocenti, F., Bellia, G., Tosin, M., Kapanen, A., and Itävaara, M. (2001). Detection of toxicity released by biodegradable plastics after composting in activated vermiculite. Polym. Degrad. Stab. 73, 101-106. doi: 10.1016/S01413910(01)00075-1

Dondero, F., Jonsson, H., Rebelo, M., Pesce, G., Berti, E., Pons, G., et al. (2006). Cellular responses to environmental contaminants in amoebic cells of the slime mould Dictyostelium discoideum. Comp. Biochem. Physiol. C 143, 150-157. doi: 10.1016/j.cbpc.2006.01.005

FD X 31-251 (1994). Qualité du Sol-Effets des Polluants vis á vis des Vers de Terre (Eisenia fetida)-Partie 1: Détermination de la Toxicité Aiguë en Utilisant des Substrats de Sol Artificiel.

Fritz, I. (2014). "Ecotoxicological aspects of the biodegradation process of polymers," in Handbook of Biodegradable Polymers, 2nd Edn., ed C. Bastioli (Shrewsbury: Smithers Rapra Shawbury), 91-138.

ISO 6341 (2012). Water Quality - Determination of the Inhibition of the Mobility of Daphnia Magna Straus (Cladocera, Crustacea) - Acute Toxicity Test. Geneva: International Organization for Standardization.

ISO 8692 (2004). Water Quality - Freshwater Algal Growth Inhibition Test with Unicellular Green Algae. Geneva: International Organization for Standardization.

ISO 11348-3 (2007). Water Quality - Determination of the Inhibitory Effect of Water Samples on the Light Emission of Vibrio fischeri (Luminescent Bacteria Test) - Part 3: Method Using Freeze-Dried Bacteria. Geneva: International Organization for Standardization.

ISO 14238 (2012). Soil Quality - Biological Methods - Determination of Nitrogen Mineralization and Nitrification in Soils and the Influence of Chemicals on these Processes. Geneva: International Organization for Standardization.

ISO 17556 (2012). Plastics-Determination of the Ultimate Aerobic Biodegradability of Plastic Materials in Soil by Measuring the Oxygen Demand in a Respirometer or the Amount of Carbon Dioxide Evolved. Geneva: International Organization for Standardization.

Kapanen, A. (2012). Ecotoxicity Assessment of Biodegradable Plastics and Sewage Sludge in Compost and in Soil. Academic dissertation in Microbiology, Helsinki, University of Helsinki.

Kyrikou, I., and Briassoulis, D. (2007). Biodegradation of agricultural plastic films: a critical review. J. Polym. Environ. 15, 125-150. doi: 10.1007/s10924-0070053-8

NF T 90-375 (1998). Qualité de L'eau - Détermination de la Toxicité Chronique des Eaux par Inhibition de la Croissance de L'algue D'eau Douce Pseudokirchneriella subcapitata (Selenastrum capricornutum).

OECD (2004). Guideline for Testing of Chemicals. No. 222. Earthworm Reproduction Test (Eisenia fetida/andrei). Paris: Organization for Economic Cooperation and Development.

OECD (2006). Guideline for the Testing of Chemicals 208: Terrestrial Plant Test: Seedling Emergence and Seedling Growth Test. Paris: Organization for Economic Cooperation and Development.

OECD (2012). Guideline for Testing of Chemicals. No. 211. Daphnia magna Reproduction Test. Paris: Organization for Economic Cooperation and Development.

PlasticsEurope (2015). Plastics - the Facts 2014/2015 An Analysis of European Plastics Production, Demand and Waste Data. Available online at: http://www. plasticseurope.org/documents/document/20150227150049-final_plastics_the_ facts_2014_2015_260215.pdf

Sforzini, S., Dagnino, A., Torrielli, S., Dondero, F., Fenoglio, S., Negri, A., et al. (2008). Use of highly sensitive sublethal stress responses in the social amoeba Dictyostelium discoideum for an assessment of freshwater quality. Sci. Tot. Environ. 395, 101-108. doi: 10.1016/j.scitotenv.2008. 01.056

Shen, L., Haufe, J., and Patel, M. K. (2009). Product Overview and Market Projection of Merging Bio-Based Plastics. PRO_BIP 2009. Final Report, Group Science, Technology and Society (STS), Copernicus Institute for Sustainable Development and Innovation, Utrecht University, Utrecht.

Spurgeon, D. J., Hopkin, S. P., Jones, D. T. (1994). Effects of cadmium, copper, lead and zinc on growth, reproduction and survival of the earthworm Eisenia fetida (Savigny): assessing the environmental impact of point-source metal contamination in terrestrial ecosystems. Environ. Pollut. 84, 123-130. doi: 10.1016/0269-7491(94)90094-9

Tuominen, J., Kylmä, J., Kapanen, A., Venelampi, O., Itävaara, M., and Seppälä, J. (2002). Biodegradation of lactic acid based polymers under controlled composting conditions and evaluation of the ecotoxicological impact. Biomacromolecules 3, 445-455. doi: 10.1021/bm01 01522

UNEP (2014). UNEP Year Book 2014 Emerging Issues Update, Plastic Debris in the Ocean. Available online at: http://www.unep.org/yearbook/2014/PDF/chapt8. pdf

UNI 11495 (2013). Biodegradable Thermoplastic Materials For Use In Agriculture And Horticulture - Mulching Films - Requirements And Test Methods. UNI Ente Nazionale Italiano di Unificazione, Italy.

UNICHIM N. 1651 (2003). Qualità dell'acqua - Determinazione dell'inibizione della Germinazione e Allungamento Radicale in Cucumis sativus L. (Cetriolo), Lepidium sativum L. (Crescione), Sorghum saccharatum Moench (Sorgo). Saggio di Tossicità Cronica Breve. Milano: UNICHIM.

van der Zee, M. (2014). "Methods for evaluating the biodegradability of environmentally degradable polymers," in Handbook of Biodegradable Polymers, 2nd Edn., ed C. Bastioli (Shrewsbury: Smithers Rapra Shawbury), $1-28$.

Van Gestel, C. A., Dirven-Van Breemen, E. M., Baerselman, R., Emans, H. J., Janssen, J. A., Postuma, R., et al. (1992). Comparison of sublethal and lethal criteria for nine different chemicals in standardized toxicity tests using the earthworm Eisenia andrei. Ecotoxicol. Environ. Saf. 23, 206-220. doi: 10.1016/0147-6513(92)90059-C

Violante, P., and Adamo, P. (2000). "II. Reazione," in Metodi di Analisi Chimica del Suolo, ed P. Violante (Milano: Franco Angeli), 1-13.

Wallace Hayes, A., Kruger, C. L. (2014). Hayes' Principles and Methods of Toxicology, 6th Edn. Boca Raton: CRC Press.

Watts, D. J., Ashworth, J. M. (1970). Growth of myxamoebae of the cellular slime mould Dictyostelium discoideum in axenic culture. Biochem. J. 119, 171-174. doi: 10.1042/bj1190171

World Economic Forum (2016). Ellen MacArthur Foundation and McKinsey \& Company, The New Plastics Economy - Rethinking the Future of Plastics. Available online at: https:/www.ellenmacarthurfoundation.org/assets/ downloads/EllenMacArthurFoundation_TheNewPlasticsEconomy_15-3-16. pdf

Conflict of Interest Statement: The authors declare that the research was conducted in the absence of any commercial or financial relationships that could be construed as a potential conflict of interest.

Copyright (c) 2016 Sforzini, Oliveri, Chinaglia and Viarengo. This is an openaccess article distributed under the terms of the Creative Commons Attribution License (CC BY). The use, distribution or reproduction in other forums is permitted, provided the original author(s) or licensor are credited and that the original publication in this journal is cited, in accordance with accepted academic practice. No use, distribution or reproduction is permitted which does not comply with these terms. 